УДК 37.013.43

\title{
ПРЕДПОСЫЛКИ ЭКОЛОГИЧЕСКОЙ И БИОЭТИЧЕСКОЙ ТЕМАТИКИ В ПЕДАГОГИКЕ СССР ДО 1950-Х ГОДОВ И РУССКОГО ЗАРУБЕЖЬЯ
}

\author{
Кюрегина Анна Викторовна \\ к.п.н., доцент кафедры иностранных языков \\ ФГБОУ ВО «Национальный исследовательский университет \\ «Московский энергетический институт»
}

Аннотация: В настоящей статье производится сравнение предпосылок формирования ценностного отношения к живой природе в первую половину существования СССР и в среде российской эмиграции. Нами было выявлено, что присущие педагогике Русского зарубежья аксиологический подход к формированию личности и установка на самостоятельное мышление способствовали этому в большей степени, чем классовый, технократический подход, характерный для педагогики СССР до 1950-х годов. Вместе с тем и в Советском Союзе, и в Русском зарубежье естественнонаучные исследования благоприятствовали пониманию единства человека и природы, их подчиненности одним законам; и в нашей стране, и в русскоязычном сообществе за рубежом происходило осознание необходимости междисциплинарного изучения природы. Однако ни в Советском Союзе до 1950-х годов, ни в эмигрантской среде не производилось системной методической работы, направленной на выработку этичного отношения к живым существам.

Ключевые слова: аксиологический подход к образованию, технократический подход к образованию, краеведческий метод, природоохранное и биоэтическое воспитание, целостный подход к изучению окружающего мира, преобразующее обучение, антропоцентрические и биоцентрические убеждения. 


\section{PREREQUISITES OF ENVIRONMENTAL AND BIOETHICAL THEMES IN THE PEDAGOGY OF THE USSR BEFORE 1950-IES AND RUSSIAN EMIGRATION}

\section{Kiuregina Anna Viktorovna}

Abstract: The article compares the prerequisites of developing moral attitudes to living nature in the USSR during the first half of its existence and among Russian emigration. It was revealed that axiological approach to personality formation and striving for independent thinking typical for Russian emigration contributed to it more than class technocratic approach typical for Soviet pedagogy till the 1950-ies. Still both in the Soviet Union and among Russian emigrants natural researches contributed to the understanding of unity of people and nature, their subordination to the same laws; both in our country and in the Russian speaking community abroad the necessity of multidisciplinary studying of nature was being realized. Still systematic methodic work aimed at developing ethical attitude to living beings was not carried out either in the Soviet Union before the 1950-ies or among emigrants.

Key words: axiological approach to education, technocratic approach to education, method of regional studies, natural protective and bioethical education, comprehensive approach to studying the environment, transformative learning, anthropocentric and biocentric convictions.

В наши дни в условиях социально-экологического кризиса интерес представляют мировоззренческие принципы, касающиеся взаимодействия человека и природы, закладываемые в процессе образования и воспитания и приведшие к текущему неблагоприятному положению дел. В настоящем исследовании мы сравним подходы, связанные с формированием ценностных установок к жизни и природе, в Советском Союзе до 1950-х годов и в среде российской эмиграции. Это позволит выявить сходства и различия, присущие становлению природоохранных ориентиров молодежи в период научнотехнической революции в разных политических и социальных условиях. Отметим, что для исследования предпосылок формирования этичного отношения к живой природе значение имеют аспекты педагогики и философии, не только касающиеся непосредственно природоохранного и биоэтического воспитания, но и смежные с данной сферой, влияющие на готовность человека 
принять эти идеи при соприкосновении с ними в ближайшей или отдаленной перспективе.

Известно, что принципиальным различием между философскими и педагогическими трудами, создаваемыми в СССР и в эмиграции, оказалось наличие ограничений вследствие господства официальной идеологии в первом случае и отсутствие таковых во втором. Так, уже в 1930-е годы перед учеными ставятся задачи проводить исследования, в соответствии с хозяйственными нуждами, при этом ключевое значение придается тому, чтобы содержание и направления научной и педагогической работы соответствовали марксистской идеологии [1; 2]. В то же время в среде русскоязычной эмиграции доминировала мысль о нежелательности дедуктивного мышления в процессе получения образования, о способности к самостоятельному мышлению как показателе интеллекта (И.А. Ильин [3; 4, с. 798]), о необходимости находить свой собственный путь в жизни (С.И. Гессен [5]). Как указывают современные исследователи, в эмигрантской среде присутствовала тенденция рассматривать жизненный путь человека обособленно от внешних событий, а в советской педагогике, напротив, подчеркивалась их зависимость [6; 7]. Таким образом, педагогика Русского зарубежья открывала больше возможностей, чем советская педагогика, для переосмысления норм обращения с миром природы, поиска путей минимизации вреда живым существам. Также современные исследователи отмечают преобладание технократического подхода к образованию в СССР и аксиологического в Русском зарубежье. Если в СССР, особенно до 1950-х годов содержание, цель и задачи образования в значительной мере определялись вопросами политики и хозяйственноэкономической целесообразности, то в Русском зарубежье его регулятором служили ценностные ориентиры [6; 7].

В то же время, в тот период одним из значительных достижений философской и педагогической мысли на стыке с идеями ценностного отношения ко всему живому как на территории СССР, так и в эмиграции стали труды космистов, где подчеркивалась взаимосвязь человека со Вселенной, космосом, подчиненность одинаковым законам. Так, если в СССР разрабатывается идея биосферы и ноосферы (В.И. Вернадский [8]), вводится понятие микрокосм применительно к человеку и макрокосм применительно к окружающему миру (Павел Флоренский [9]), предлагается концепция антропокосмизма (Н.Г. Холодный [10]), то в среде эмигрантов имеет место идея совершенствования человека и мира (Н.А. Сетницкий [11]), сотрудничества с 
природой ввиду того, что человек является ее частью, связи между культурным уровнем людей и состоянием окружающего мира (Н.К. Рерих, Е.И. Рерих [12]). Таким образом, в идеях космистов прослеживаются основы современной философии устойчивого развития, заключающейся в росте человеческого благосостояния, в соответствии с законами природы, с учетом далеко идущих последствий преобразований, совершаемых человеком.

Между тем идея целостного, подхода к изучению окружающего мира, взаимосвязанности природных явлений нашла отражение в активном развитии междисциплинарных отраслей знаний, наблюдавшемся как в СССР, так и в Русском зарубежье. Так, в 1920-е годы в Советском Союзе активно развивался краеведческий метод в педагогике, базирующийся на изучении общественных явлений в контексте природной среды; под эгидой Наркомпроса создаются и развиваются заповедники, позволяющие изучать экологию сообществ, исследовать многочисленные связи в живой природе; распространение получают понятия «экология сообществ», «биогеоценоз» [13]. Тогда же в эмиграции Н.К. Рерих и Е.И. Рерих отмечают, что именно наблюдение за природой открывает возможности для формирования синтетического мышления, способности понимать сущность наблюдаемых объектов и явлений [12]. Как в СССР (В.В. Станчинский [14], В.Н. Сукачев [15]), так и в Русском зарубежье (С.Н. Виноградский [16]) осознается необходимость взаимодействия экологии с другими науками. То есть, закладывается взгляд на экологию как на междисциплинарную сферу знаний, и, соответственно, на экологическое воспитание как на задачу, требующую комплексного решения.

Однако исследование трудов как прогрессивных советских педагогов, так и эмигрантов позволяет установить, что в их трудах проявляется идея недопустимости научного прогресса вне этики. В частности, данная тематика прослеживается в трудах В.И. Вернадского [8], Н.Г. Холодного [10], И.А. Ильина [4, с. 676-682, 800], В.В. Зеньковского [17, с. 43-44] и других ученых. Вместе с тем, нами выявлены такие идеи лишь в теоретических трудах; как в СССР, так и в русскоязычном сообществе вне России в данной сфере не велось целенаправленной методической и практической работы. Но за рубежом, как известно, в тот период времени набирали силу коммерческие интересы, ориентированные на создание потребительского общества и увеличение прибыли и оказывавшие влияние на разные стороны человеческой жизни, поэтому условий для проникновения идеи взаимообусловленности науки и нравственности в массовое сознание не было создано. В СССР же в 
условиях роста военно-промышленного комплекса, укрепления тоталитарного режима, и малого развития идей гуманизма, ценностного отношения ко всему живому в более ранние периоды времени этические императивы также не могли служить регулирующим фактором для развития науки и техники.

В отечественной педагогике с 1917 года по середину XX века нам не удалось найти учебно-методических трудов, направленных на формирование у школьников и молодежи этичного отношения к живым существам, отличным от человека. Однако в первое послереволюционное десятилетие ярким феноменом российской общественно-культурной жизни, связанным с воспитанием ценностного отношения к природе, стало развитие толстовского движения, толстовских школ, где учащиеся воспитывались, в соответствии с идеей ценности всякой жизни [18]. Между тем, широкого влияния на педагогику это движение не оказало, в значительной мере потому что его участники жили обособленно и просуществовало недолго - в 1930-е годы оно подверглось репрессиям и фактически оказалось под запретом. За рубежом, в особенности, в Канаде, в тот же период времени наблюдается развитие религиозного движения духоборов, которые имели связь с Л.Н. Толстым и его последователями и покинули Россию незадолго до революции [19, с. 134-138]. Они придерживались ценностей, основывающихся на минимизации вреда всяким живым существам и ненасилии. Немаловажно, что как в среде толстовцев, так и в среде духоборов главенствующую роль играла идея взаимосвязи жестокости к людям и к животным, необходимости последовательного отказа от нее, в частности, пацифизм, с одной стороны и неприятие традиционно практикуемой жестокости к живым существам, например, в сельском хозяйстве. Очевидно, опыт воспитания детей в толстовских поселениях в России и среди духоборов за рубежом можно рассматривать как эмпирическую предпосылку к современному преобразующему обучению, получающему распространение за рубежом и в России, ориентированному на пересмотр системы убеждений с антропоцентрических на биоцентрические, и принятие биоэтически грамотного образа жизни.

Но разносторонний педагогический опыт толстовцев и духоборов, направленный на формирование ценностного отношения к животным, оказался практически не отражен в дидактической и методической литературе. В период с 1917 года до середины ХХ века указания непосредственно на важность воспитания этичного отношения к живой природе в наиболее четкой форме 
присутствуют в философских и педагогических трудах представителя Русского зарубежья Н.О. Лосского. Он указывал, что нравственный поступок - тот, который основан на уважении к любой жизни, не только человеческой, а безнравственный - тот, который вызывает чувство неловкости и толкает на иной способ решения возникшей проблемы, и подчеркивал, что именно стремление минимизировать вред всему живому составляет основу эволюции, что многие беды человечества происходят из-за неспособности к гармоничному сосуществованию с окружающим миром [20, с. 132-133, 135].

Таким образом, в целом, мировоззренческие принципы, закладываемые в педагогике Русского зарубежья в большей ступени способствовали формированию ценностного отношения к живым существам, и обусловлено это было отчасти политическими обстоятельствами, отчасти тем фактом, что в эмиграции после 1917 года оказалась наиболее образованная и мыслящая часть социума. Между тем развитие науки как в СССР, так и в Русском зарубежье способствовало укреплению мысли о человеке как интегральной части природы. Но целенаправленной работы, направленной на выработку норм этичного взаимодействия с живыми существами, не велось, передовые идеи, высказываемые отдельными педагогами, не получали распространения в образовании, тогда как научно-техническая революция и промышленные императивы укрепляли в массовом сознании мысль о необходимости покорения окружающему мира, получения максимальной выгоды. Поэтому перспективы теоретических и практических исследований нам видятся в анализе идей прогрессивных ученых СССР и русской эмиграции и внедрении их в практику с учетом современных реалий; изучении педагогического опыта толстовцев и духоборов и определении возможностей использования некоторых его аспектов; интеграции идей ценностного отношения к природе в среднее и высшее образование.

\section{Список литературы}

1. Презент И.И. Классовая борьба на естественно-научном фронте. М.Л.: ОГиз-Учпедгиз, 1932. - 72 с.

2. Толстов С.П. Студенчество и краеведение. М.: Издание Центрального бюро краеведения, 1930. 56 с.

3. Ильин И.А. Что за люди коммунисты? // Ильин И.А. Наши задачи. Статьи 1948-1954 гг. Том 2. Париж: Издание Русского Обще-Воинского Союза, 1956. С. 506-510. 
4. Ильин И.А. Путь к очевидности. // Ильин И.А. Путь к очевидности: сочинения. М.: ЭКСМО-пресс, 1998. 912 с.

5. Гессен С.И. Мировоззрение и образование // Хрестоматия. Педагогика Российского зарубежья / Сост. Е.Г. Осовский, О.Е. Осовский. М.: Институт практической психологии. 1996. С. 147-168.

6. Богомолова Л.И. Педагогика российского зарубежья в контексте диалога // Российское Зарубежье: образование, педагогика, культура. 20-50-е годы XX века: Материалы Второй Всерос. науч. конф. «Образование и пед. мысль Рос. Зарубежья. 20-50-е годы ХХ века» (Саранск, 16-18 окт. 1997 г.) / под ред. чл.-корр. РАО, д-ра пед. наук, проф. Е. Г. Осовского. Саранск: МГПУ им. М.Е. Евсевьева, 1998. С.62-67.

7. Осовский Е.Г. Российское зарубежье: педагогическая наука в изгнании (20-е - 30-е годы XX века) // Российское Зарубежье: образование, педагогика, культура. 20-50-е годы XX века: Материалы Второй Всерос. науч. конф. «Образование и пед. мысль Рос. Зарубежья. 20-50-е годы XX века» (Саранск, 16-18 окт. 1997 г.) / под ред. чл.-корр. РАО, д-ра пед. наук, проф. Е.Г. Осовского. Саранск: МГПУ им. М.Е. Евсевьева, 1998. С. 8-22.

8. Вернадский В.И. Биосфера и ноосфера. М.: Наука, 1989. - 261 с.

9. Флоренский П. Макрокосм и микрокосм // Богословские труды. Сборник 24. М.: Издание Московской патриархии, 1983. С. 230-241.

10. Холодный Н.Г. Мысли натуралиста о природе и человеке // Русский космизм: антология философской мысли / сост. и предисл. к текстам С. Г. Семеновой, А. Г. Гачевой; примеч. А. Г. Гачевой. М.: Педагогика-пресс, 1993. $365 \mathrm{c}$.

11. Сетницкий Н.А. О конечном идеале // Путь. - №36. - 1932. - С. 93-95.

12. Агни Йога (Знаки Агни Йоги). М.: Международный Центр Рерихов, 2008. $600 \mathrm{c}$.

13. Озеров П.В. Краеведение и национальное студенчество М.: Издание Главнауки и Центрального бюро краеведения, 1929. 22 с.

14. Станчинский В.В. Среда жизни и ее подразделения // Труды Зоологобиологического института Харьковского. университета. 1933. Т. 1, вып. 1: Проблемы биоценологии. С. 38-56.

15. Сукачев В.Н. О соотношении понятий "географический ландшафт" и "биогеоценоз" // Вопросы географии. М.: Географгиз, 1949. Вып. 16. С. 45-60.

16. Виноградский С.Н. Летопись нашей жизни // Архив РАН; Институт микробиологии им. С.Н. Виноградского РАН: Редкол.: Афиани В.Ю., Гальченко В.Ф., Пименов Н.В. и др. М.: МАКС Пресс, 2013. - 808 с. 
17. Зеньковский В.В. Педагогика. М.: Издательство Православного СвятоТихоновского Богословского Института, 1996. 153 с.

18. Воспоминания крестьян-толстовцев. 1910-1930-е годы. Сост. А.Б. Рогинский. М.: Книга, 1989. - 480 с.

19. Бранг П. Россия неизвестная. История культуры вегетарианских образов жизни от начала до наших дней. М.: Языки славянской культуры, 2006. - 568 c. С. $134-138$.

20. Лосский Н.О. Условия абсолютного добра: Основы этики // Н.О. Лосский. Условия абсолютного добра: основы этики; Характер русского народа. М.: Политиздат, 1991. С. 24-235.

(C) А.В. Кюрегина, 2021 